\title{
Nanoparticles Synthesised in the Gas-Phase and Their Applications in Sensors: A Review
}

\author{
Evangelos Skotadis *(D), Evangelos Aslanidis, Maria Kainourgiaki and Dimitris Tsoukalas * \\ Department of Applied Physics, National Technical University of Athens, 15780 Athens, Greece; \\ evaaslani@central.ntua.gr (E.A.); mkainourgiaki@mail.ntua.gr (M.K.) \\ * Correspondence: evskotad@central.ntua.gr (E.S.); dtsouk@central.ntua.gr (D.T.); Tel.: +30-21-077-22-929 (E.S.)
}

Received: 1 October 2020; Accepted: 27 October 2020; Published: 3 November 2020

\begin{abstract}
This article aims to provide a comprehensive review of recent advances in the use of gas-phase synthesized nanoparticles in the field of sensing technology. Since there are numerous and diverse reviews that already cover the subject extensively, this review focuses predominantly but not exclusively on gas-phase synthesized metallic nanoparticles and their most prominent sensing-applications. After a brief overview on the main uses of nanoparticles in science and technology, as well as a description of the dominant fabrication methods, the review discusses their incorporation in strain-sensing, chemical sensing and bio-sensing as well as a few other sensing-applications. The review highlights the inherent advantages of nanoparticles, as well as how they combine with flexible gas-phase synthesis processes.
\end{abstract}

Keywords: biosensors; chemical sensors; gas phase; gas sensors; nanoparticles; sputtering; strain sensors

\section{Introduction}

Nanotechnology has been one of the main driving forces over the recent past in scientific fields as diverse as material science, physics, electronics, biotechnology, medicine, etc. The main focus of nanotechnology is the implementation of materials with dimensions in the nanometer scale in devices. Macroscopic materials' fundamental properties drastically change when they are shrunk to a size that is comparable to that of DNA, viruses and atoms, highlighting an enormous potential for unique and novel technologies. Nanomaterials can be considered as artificial atoms that can be combined so as to obtain new materials with unprecedented properties in an always expanding field of possible applications.

Organic, inorganic or metallic nanoparticles (NPs), remain to date amongst the most studied of nanomaterials. There is an abundance of original scientific reports as well as reviews related to the properties and possible uses of individual organic NPs, inorganic NPs, NP ensembles, metal oxides, dendrimers, proteins, micelles etc.: targeted drug delivery [1], molecular biotechnology [2], the use of metal oxide nanoparticles as antibacterial agents [3], their combination with polymers [4], their use as nano-sized power generators [5] and in environmental remediation [6], are only a few of their possible applications.

Metallic nanoparticles in particular, are widely and commonly employed as active materials in various applications such as optical sensors [7], in light-based technologies [8], as potent antimicrobial materials [9], in chemical and biological sensing [10], in catalysis [11], in drug delivery [12], in imaging applications [13], in sustainable energy technology [14] and in energy-harvesting [15]. Apart from metallic NPs consisting of a single metal, bimetallic NPs synthesized as alloys or core-shell structures are also used in a wide range of applications [16]. The integration of NPs in sensing technology is of particular interest since their high surface/volume ratio and unique optical, chemical and electrical properties render them as ideal active materials in almost any sensing scenario. Solid Au NPs have been studied extensively as chemiresistive [17] or plasmonic surface enhancement for Raman scattering-based 
devices [18], for the chemical sensing of volatile organic compounds (VOCs), biosensors [19], sensors for infectious diseases [20], environmental sensing [21], food quality inspection [22] as well as strain sensing [23].

The current review aims to report on recent research efforts on sensing devices, based on NPs grown by physical methods with emphasis on gas-phase grown NPs. Strictly speaking, the gas phase manufacturing technique of bare metallic NPs, utilizes processes that will be described in Section 2 and are illustrated in Figure 1. However, in this review we also consider sensors that make use of bare NPs formed by the two-step process, namely physical deposition and annealing of a thin metal layer. We believe that the latter investigations are of interest for researchers using NP deposition by the gas phase technique since performing the NP fabrication at room temperature (R.T.) and in a single step, can be an attractive alternative method for replacing the two-step process. The article begins by briefly discussing the gas-phase technique for NP synthesis as well as the chemical and biosynthesis of NPs. The second part of the review showcases recent results related to strain-sensors as well as a few other types of devices. In the second part of the review a brief description regarding charge-transport and the strain-sensing mechanism in the case of gas-phase NPs will be also provided; this discussion relates directly to other types of sensors discussed in the following sections of the article. As a next step the review discusses one of the most reported type of sensing-devices employing gas-phase NPs, i.e., chemical or gas-sensors and will finally report on recent progress in the fields of bio-sensing. It is the authors hope that after a thorough review on recent advances in this field, the reader will appreciate the flexibility and the advantages offered by gas-phase generated NPs, in the design of a sensing device.

\section{Nanoparticle Synthesis}

\subsection{Gas-Phase Nanoparticle Synthesis}

One of the most common methods for NP synthesis is the one employing the physical vapour deposition (PVD) technique of direct current (DC) or radio frequency (RF) sputtering; this technique does not feature any dangerous chemical reagents or complex chemical synthesis steps. In DC sputtering a metallic target is bombarded by ions of an inert gas; in this way, gas-phase atoms from the target's surface are detached and due to a pressure difference between the nanoparticle generation chamber and the deposition chamber (Figure 1), they start to condensate whilst moving towards the deposition chamber. This process allows for facile NP size control as well as NP surface coverage on top of the deposition substrate; in addition, the entire process is conducted in R.T. Metallic nanoparticles can be also formed using sputtering of a metal target when this is followed by thermal treatment of the deposited metallic film that results in material aggregation and thus NP formation. The sputtering technique is common in the microelectronics industry hence suitable for mass production and batch fabrication, as well as in research. Today, there exists a great number of publications related to sputtering's principles, theoretical studies for particle formation as well as modifications on sputtering systems so as to obtain improved properties [24]. Since a detailed discussion related to sputtering is outside the scope of the current review, readers interested on the subject are strongly encouraged to consult the relevant publications.

\subsection{Alternative Methods for NP Synthesis}

Perhaps the most common method for NP synthesis as well as shape-control is the one based on chemical methods [25] that have been covered extensively in the literature; such methods produce NPs that are commonly called colloidal. In brief, colloidal NCs are synthesized in a liquid solution containing some stabilizing organic molecules, broadly termed as surfactants. As extracted from their growing medium, they are typically made of a crystalline core with the desired chemical composition and a monolayer surface shell of tightly coordinated surfactants that provide them with solubility and, hence, with colloidal stability. In addition, surfactants can tune the overall physiochemical properties of the NPs. In colloidal synthesis, molecular precursors containing the atomic species that will form the NCs are introduced into a flask and allowed to react or decompose at a suitable temperature [26]. 
More recently, the green-synthesis of biogenic NPs (NPs deriving from biomaterials) has also attracted attention, by providing cost-effective and easy to prepare NPs that employ eco-friendly materials. Amongst the key advantages that this technique offers over chemical synthesis methods, is the biological capacity to catalyze reactions in aqueous media at standard temperature and pressure [27]. The biological synthesis of nanoparticles is a bottom-up approach that involves the use of living prokaryotic/eukaryotic cells, biomolecules extracted from living cells and cell free supernatant or extracted biomolecules; these can act as reducing or capping agents for NP formation. The biogenic NP synthesis is enabled by key enzymes (e.g., oxidoreductases, NADH-dependent reductases etc.) that are present in biomaterials, which can first bind to metallic ions and then reduce them. Today, many reports can be found on the extracellular synthesis of metallic NPs, by using different bacterial strains, fungal species, yeasts and plant or flower extracts as bio-nanofactories for eco-friendly-one-step-rapid synthesis NP formation [28].

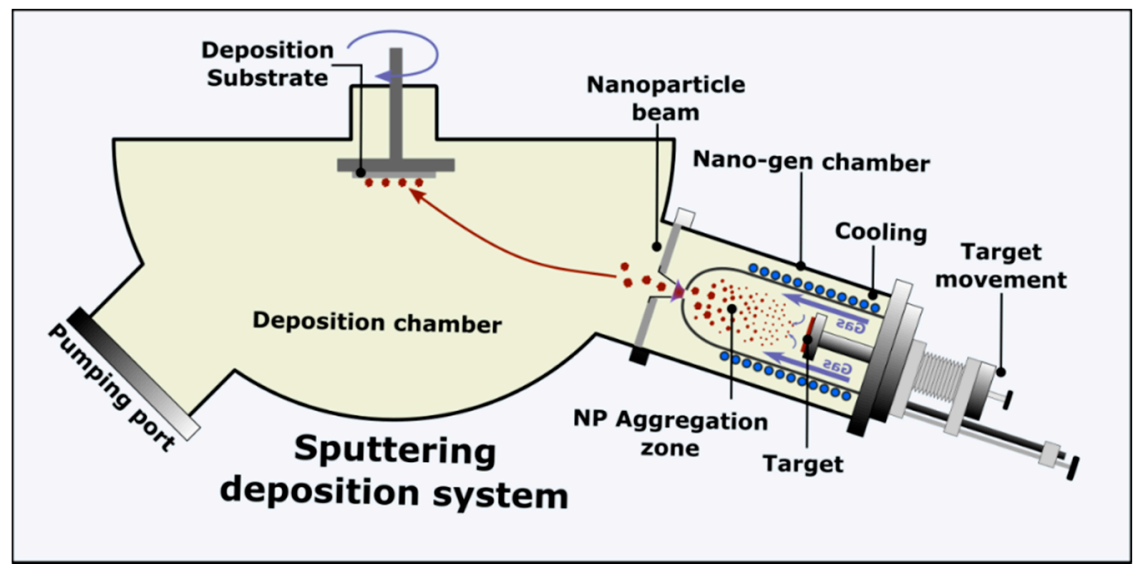

(a)

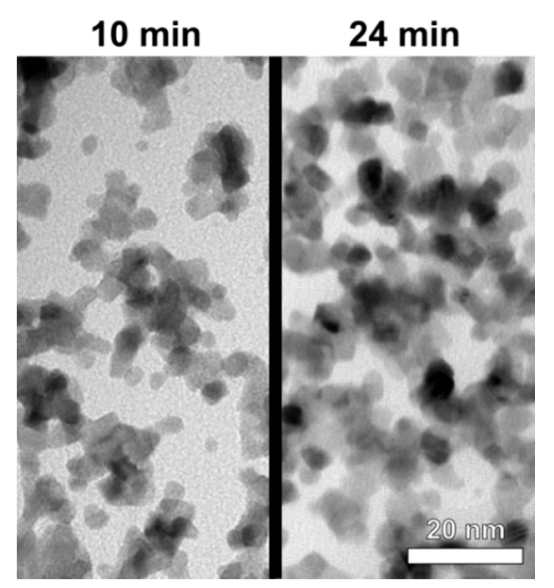

(b)

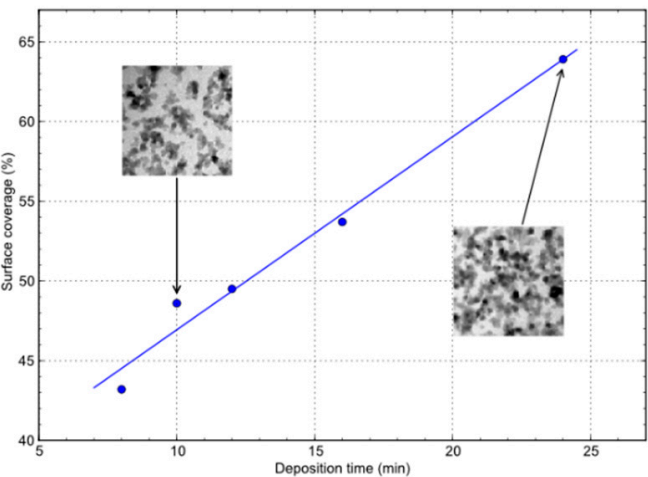

(c)

Figure 1. (a) Schematic of a typical ion-sputtering system. Key components can be seen in the Deposition and Nano-gen chambers (b) Bright field TEM micrographs comparing NP film surface coverage for varying deposition time (10 $\mathrm{min}$ and $24 \mathrm{~min}$ ). (c) Surface coverage in relation to deposition time. Figure 1b,c reprinted from [29], with permission from Elsevier.

\section{Strain Sensors and Other Devices}

This part of the review will deal with recent advances mainly in the field of strain sensing. Since the conductivity of gas-phase, NP-based sensors can be tuned by modifying the surface coverage/density of the NP film on the substrate's surface, devices of varying conductivity can be produced. Strain sensing 
devices can either utilize NP films with a conductivity that lies just below the percolation threshold (conductivity via an activated tunnelling mechanism), dense "metallic" type films as well as employing cracked substrates (oxides etc.) in order to further enhance the sensitivity (usually indicated by the gauge factor, GF) of the device. All results discussed in the current section are summarized in Table 1. Section 3.1 discusses the physical mechanisms of charge transport phenomena in the case of sensors based on gas-phase synthesized NPs; this discussion is also relevant to devices presented in Sections 4 and 5 of this review.

\subsection{Conductivity in Metallic NP Films, Strain-Sensing Mechanism}

The operational principle of nanoparticle-based sensors is based on the fact that NPs have an inter-particle distance, which is key to the conductivity of the device. Assuming that the inter-particle distance is defined by 1 , the conductivity is given by the following equation:

$$
\mathrm{R}=\mathrm{r}_{0} \exp (\beta 1) \exp \left(\mathrm{E}_{\mathrm{c}} / \mathrm{k}_{\mathrm{b}} \mathrm{T}\right)
$$

where $\beta$ is the tunneling constant, $r_{0}$ a pre-exponential constant, $\mathrm{k}_{\mathrm{b}}$ is the Boltzmann constant, $\mathrm{T}$ the temperature and $\mathrm{E}_{\mathrm{c}}$ the activation energy which is given by:

$$
\mathrm{E}_{\mathrm{c}}=\left(\mathrm{e}^{2} / 8 \pi \varepsilon \varepsilon_{0}\right)[1 / \mathrm{r}-1 /(\mathrm{r}+1)]
$$

where, $\mathrm{r}$ is the mean diameter of the nanoparticles and $\varepsilon$ the electric permittivity of the dielectric medium. At R.T. $\mathrm{E}_{\mathrm{c}}\left(\mathrm{K}_{\mathrm{b}} \mathrm{T}\right) \ll 1$. Herrmann et al. [30], have proposed a theory suggesting that the differential resistance change is given by the following equation:

$$
\Delta \mathrm{R} / \mathrm{R}=\exp (\mathrm{g} \gamma)-1
$$

where, $\mathrm{g}$ is the strain sensitivity or the strain G.F. and $\gamma$ the deformation. For small $\gamma$, Equation (3) becomes:

$$
\Delta \mathrm{R} / \mathrm{R}=\mathrm{g} \gamma
$$

this is the case for chemically synthesized, solvent-based, cross-linked NP sensors.

Aslanidis et al. [31] have shown that there is a need to modify the previous equations so as to account for changes introduced in the case of gas-phase NP sensors, highlighting that Equation (3) is not adequate to describe their performance. Relative resistance changes in the case of gas-phase NP sensors, display strain ranges that can be described with a linear Equation (4) and others where they are still linear but with a different slope and therefore different sensitivity; this cannot be accounted for by the cross-linked NPs model. In their study, Aslanidis et al. conclude that new inter-particle gaps are formed during device bending. These new gaps are critical for device sensitivity, increasing its G.F. above a specific strain-threshold. In fact, the new G.F. (g) of the device can be calculated by the following equation:

$$
\Delta \mathrm{R} / \mathrm{R}_{0}=\gamma\left(\mathrm{g}+\mathrm{kr}_{0} / \mathrm{R}_{0}+\mathrm{k}^{\prime} \mathrm{r}_{0} / \mathrm{R}_{0}\right)
$$

Equation (5) is linear, with different slopes and has proven to fit more accurately the behaviour of gas-phase NP sensors than the previously reported model. 
Table 1. Gas-phase NP strain-sensors.

\begin{tabular}{|c|c|c|c|c|}
\hline Authors/Year [Ref] & Active Material & Sensor Type & Sensitivity & Notes \\
\hline Tanner et al./2012 [32] & Pt NPs & Strain-sensor & 75 G.F. & $\begin{array}{l}\text { Gas-phase NPs, } \\
\text { Si substrate }\end{array}$ \\
\hline Zheng et al./2014 [33] & Cr NPs & Strain-sensor & 100 G.F. & $\begin{array}{l}\text { Gas-phase NPs, } \\
\text { PET substrate }\end{array}$ \\
\hline Xie et al./2018 [34] & Pd NPs & Strain-sensor & 1000 G.F. & $\begin{array}{c}\text { Gas-phase NPs, } \\
\text { PET substrate }\end{array}$ \\
\hline Patsiouras et al./2018 [35] & Pt NPs & Strain-sensor & 45 G.F. & $\begin{array}{c}\text { Gas-phase NPs, } \\
\text { Si substrate }\end{array}$ \\
\hline Schwebke et al./2018 [36] & Pt NPs & Strain-sensor & $\begin{array}{c}23(\mathrm{BN}), 9-9500\left(\mathrm{Al}_{2} \mathrm{O}_{3}\right) \\
\text { G.Fs }\end{array}$ & $\begin{array}{c}\text { Gas-phase NPs, } \\
\mathrm{BN} \& \mathrm{Al}_{2} \mathrm{O}_{3} \\
\text { substrate }\end{array}$ \\
\hline Min et al./2019 [37] & $\begin{array}{c}\mathrm{Ag} \\
\text { NPs/MWCNTs } \\
\text { composites }\end{array}$ & Strain/stretch-sensor & 58.7 G.F. & $\begin{array}{l}\text { Gas-phase NPs, } \\
\text { PDMS substrate }\end{array}$ \\
\hline Lee et al./2019 [38] & Ag NPs & Strain-sensor & $290.62,1056$ (cracks) & $\begin{array}{l}\text { Gas-phase NPs, } \\
\text { PI substrate }\end{array}$ \\
\hline Liu et al./2019 [39] & Pd NPs & Strain-sensor & $\begin{array}{c}55(0.3 \% \text { strain })-3500(8 \% \\
\text { strain })\end{array}$ & $\begin{array}{c}\text { Gas-phase NPs, } \\
\text { PET substrate }\end{array}$ \\
\hline Aslanidis et al. [31] & Pt NPs & Strain-sensor & $\begin{array}{l}60 \text { G.F. }(\text { strain }<0.64 \%) \\
85 \text { G.F. }(\text { strain }>0.64 \%)\end{array}$ & $\begin{array}{l}\text { Gas-phase NPs, } \\
\text { PI substrate }\end{array}$ \\
\hline Chen et al./2019 [40] & Pd NPs & Pressure-sensor/Barometer & $0.13 \mathrm{kPa}^{-1}$ & $\begin{array}{l}\text { Gas-phase NPs, } \\
\text { PET substrate }\end{array}$ \\
\hline Zhang et al./2017 [41] & $\begin{array}{c}\mathrm{Au} \mathrm{NPs} / \mathrm{UCNPs} \\
\text { structure }\end{array}$ & Temperature-sensor & $1.35 \% \mathrm{~K}^{-1}(325 \mathrm{~K})$ & $\begin{array}{l}\text { Gas-phase NPs, } \\
\text { PI substrate }\end{array}$ \\
\hline
\end{tabular}

\subsection{Review of Recent Advances in NP-Based, Strain-Sensors and Other Physical Sensors}

One of the first published results related to gas-phase NPs was that of Tanner et al. [32]; in that paper the authors took advantage of sputtering's potential for tuning the surface coverage of the device, optimizing the strain sensors performance accordingly. Highest sensitivities have been recorded for intermediate NP densities, just below the percolation threshold, where the tunnelling/hopping charge-transport mechanism is dominant. Zheng et al. [33] have deposited Cr NPs on top of flexible PET substrates. The authors produced devices dominated by quantum charge-transport phenomena, resulting in improved GF compared to semiconducting or metal foil strain sensors, as well as in a wider dynamic range with a workable maximum applied strain beyond 3\%. Xie et al. [34] used Pd NPs on top of a PET substrate in three different NP surface densities that were dominated by the hopping/tunnelling mechanism. Again, sensors with lower surface densities exhibited higher sensitivities (G.F. of 1000) as well as mechanical robustness in repeated fatigue tests. Patsiouras et al. [35] utilized thin alumina $\left(\mathrm{Al}_{2} \mathrm{O}_{3}\right)$ coatings deposited via the atomic layer deposition technique and on top of Pt NP networks, in order to study the potential of the alumina layer to act as an effective humidity barrier coating. Parameters such as alumina thickness and deposition temperature were evaluated; in addition, the effect of alumina and NP size on the GF was also studied. Schwebke et al. [36] deposited Pt NP films on boron nitride (BN) and alumina films that were previously deposited on polyimide substrates. The application of high strains (close to 1.5\%) reveals the formation of cracks in the alumina functionalized strain sensors, which translates in a gigantic resistance jump and a proportional increase in GF (from 9 to 9500). In contrast to the brittle alumina films, softer BN substrates remain linear throughout the applied strain range. Min et al. [37] used an aerodynamically focused nanomaterials (AFN) printing system (a dry printing method) in order to transfer aerosolised NPs/MWCNTs composites onto a PDMS substrate. The authors studied critical fabrication steps such as the printing process and the effect of substrate, achieving high levels of deformation (74\%) and good mechanical stability (1000 load/unload strain cycles). Lee et al. [38] studied the AFN fabrication extensively and optimized the AFN printing technique (printing patterns \& printing velocity) for the production of Ag NP strain-sensors on polyimide (PI) substrates; this resulted in sensors with a GF between 18.6 and 290.62. In addition, the authors induced mechanical cracks within the Ag NP film, thus radically increasing the GF of the device. Liu et al. [39] studied the effect of Pd NP concentration on sensor sensitivity for sensors implemented on PET substrates. Various GFs have been achieved according to the applied strain 
range. Finally, Aslanidis et al. [31] reported on alumina coatings used as a protection against humidity, for Pt NP-based flexible sensors (Figure 2). The authors established a critical alumina thickness that is suitable for protection for increased strains (flexible substrates) while at the same time submitting the device in intensive fatigue tests; in addition, they also examined the effect of alumina on sensor sensitivity. Another contribution was the proposition of a model explaining the behaviour of the sensor, as strain gradually increases (introduction of two distinctive GFs); this model highlights the difference between sensors utilizing solvent-free NPs (gas-phase) and solvent-based (colloidal) NPs.

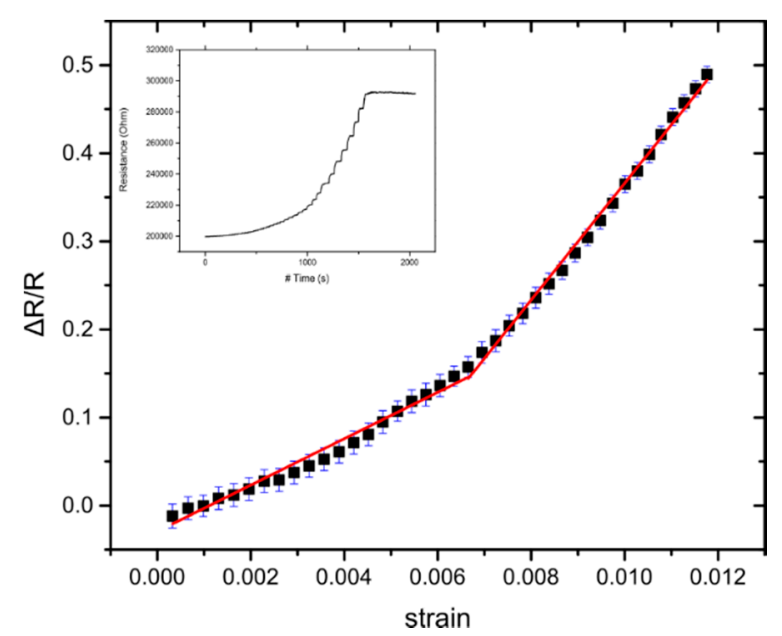

Figure 2. Measurement of resistance during gradual application of strain. Relative resistance over strain graph, where the GF is calculated by the slopes of the fitting line. Error bars represent the standard deviation of the measurements. In this particular example, the sensor has GF1 26 for lower strains and GF2 $\sim 66$ for higher strains. Inset picture shows the sensor's actual "step-like" response to gradual strain application. Reprinted from [30]

Gas-phase, NP-based sensors are also used for other types of physical sensors. Chen et al. [40] realised a highly sensitive piezoresistive sensor that can also be used as a barometer, by depositing Pd NPs on PET substrates. Contrary to traditional pressure sensors, this device transduces the external pressure on the elastic membrane on which the NPs are deposited; in this way the tunnelling conductance between the percolated NPs changes, resulting in high sensitivity. Zhang et al. [41] deposited Lanthanide-doped ( $\beta-\mathrm{NaYF}_{4}: \mathrm{Yb}^{3+} / \mathrm{Er}^{3+}$ ) upconversion nanoparticles (UCNPs), on top of gas-phase Au NPs previously deposited on microfibers. The plasma-resonance on the surface of the Au nanofilm can be excited by launching a $980 \mathrm{~nm}$-wavelength laser beam into the microfiber, resulting in an enhancement of the local electric field and a strong thermal effect. The fabricated device has proved to be able to operate as a temperature sensor.

\section{Chemical Sensors}

The field of chemical or gas sensing is the one featuring the highest number of scientific publications related to gas-phase metallic NPs. The main body of work related to gas-sensors, deals with conductometric devices that utilize noble metallic nanoparticle as catalysts combined with metal oxides, while other publications rely on the production of a hybrid NP/polymer-based device. The advantage of fabricating and depositing NPs at room temperature (RT) and in a highly controlled manner is a unique feature of gas-phase techniques that have been widely employed in order to produce a vast number of chemical sensors. All results discussed in the current section are summarized in Table 2. 
Table 2. Gas-phase NP chemical sensors.

\begin{tabular}{|c|c|c|c|c|}
\hline Authors/Year [Ref] & Active Material & Gas Target & $\begin{array}{c}\text { LoD } \\
\text { (Concentration) }\end{array}$ & Notes \\
\hline Lee et al./2016 [42] & $\begin{array}{c}\text { Au decorated } \mathrm{CuO} \\
\text { NWs }\end{array}$ & $\mathrm{CO}, \mathrm{NO}_{2}$ & $1 \mathrm{ppm}$ & Heat-treated NPs \\
\hline Kim et al. [43] & Pt decorated $\mathrm{SnO}_{2} \mathrm{NFs}$ & Toluene & $10 \mathrm{ppm}$ & Heat-treated NPs \\
\hline Wongrat et al./2016 [44] & $\mathrm{Au}$ decorated $\mathrm{ZnO}$ & $\mathrm{EtOH}$ & $100 \mathrm{ppm}$ & Heat-treated NPs \\
\hline Choi et al./2017 [45] & Pt decorated SWCNTs & $\mathrm{NO}_{2}$ & $2 \mathrm{ppm}$ & Heat-treated NPs \\
\hline Yang et al./2017 [46] & $\begin{array}{c}\text { Pd decorated } \mathrm{SnO}_{2} \text { on } \\
\mathrm{LiNbO}_{3}\end{array}$ & $\mathrm{H}_{2}$ & 100 ppm & Heat-treated NPs \\
\hline Gasparotto et al./2018 [47] & $\begin{array}{c}\text { Au decorated } \mathrm{ZnO} \\
\text { NRs }\end{array}$ & $\mathrm{H}_{2}, \mathrm{O}_{2}$ & 1996 ppm & Heat-treated NPs \\
\hline Liang et al./2018 [48] & $\begin{array}{c}\mathrm{Au} \text { decorated } \mathrm{VO}_{2} \\
\text { NWs }\end{array}$ & $\mathrm{NO}_{2}$ & $5 \mathrm{ppm}$ & Heat-treated NPs \\
\hline $\begin{array}{l}\text { Drmosh et al./2018 [49] } \\
\text { Cao et al./2019 [50] }\end{array}$ & $\begin{array}{c}\text { Au decorated } \mathrm{SnO}_{2} \\
\text { Pd decorated } \mathrm{ZnO} \text { NRs }\end{array}$ & $\begin{array}{l}\mathrm{NO}_{2} \\
\text { EtOH }\end{array}$ & $\begin{array}{l}50 \mathrm{ppm} \\
100 \mathrm{ppm}\end{array}$ & $\begin{array}{l}\text { Heat-treated NPs } \\
\text { Heat-treated NPs }\end{array}$ \\
\hline Khalid et al./2019 [51] & $\begin{array}{c}\text { Au decorated } \mathrm{SnO}_{2} \\
\text { NWs }\end{array}$ & $\mathrm{EtOH}$ & $125 \mathrm{ppm}$ & Heat-treated NPs \\
\hline Jaiswal et al./2020 [52] & Pd decorated $\mathrm{MoS}_{2}$ & $\mathrm{H}_{2}$ & $10 \mathrm{ppm}$ & Heat-treated NPs \\
\hline Liang et al./2016 [53] & $\begin{array}{c}\mathrm{Au} \text { decorated } \mathrm{VO}_{2} \\
\text { nanosheets }\end{array}$ & $\mathrm{CH}_{4}$ & 100 ppm & Gas-phase NPs \\
\hline Yuan et al./2016 [54] & $\begin{array}{c}\text { Au decorated PS/ } / \mathrm{WO}_{3} \\
\text { composites }\end{array}$ & $\mathrm{NO}_{2}$ & $50 \mathrm{ppb}$ & Gas-phase NPs \\
\hline Li et al./2017 [55] & $\begin{array}{c}\mathrm{Au} \& \mathrm{SnO}_{2} \text { decorated } \\
\mathrm{MoS}_{2} \\
\mathrm{Pd} \text { decorated }\end{array}$ & TEA & $2 \mathrm{ppm}$ & Gas-phase NPs \\
\hline Hao et al./2017 [56] & $\begin{array}{l}\mathrm{Pd} \text { decorated } \\
\mathrm{MoS}_{2} / \mathrm{SiO}_{2} / \mathrm{Si} \\
\text { heterojunction }\end{array}$ & $\mathrm{H}_{2}$ & $0.5 \%$ & Gas-phase NPs \\
\hline Vernieres et al./2017 [57] & Fe nanocubes & $\mathrm{NO}_{2}$ & $3 \mathrm{ppb}$ & Gas-phase NPs \\
\hline Dhall et al./2017 [58] & $\begin{array}{c}\text { Pt decorated } \\
\mathrm{MWCNTs} / \mathrm{TiO}_{2}\end{array}$ & $\mathrm{H}_{2}$ & $0.05 \%$ & Gas-phase NPs \\
\hline Song et al./2017 [59] & $\begin{array}{c}\text { Au decorated } \mathrm{ZnO} \\
\text { NRs }\end{array}$ & TEA & $1 \mathrm{ppm}$ & Gas-phase NPs \\
\hline Chen et al./2017 [60] & $\begin{array}{l}\text { Pd coated PMMA } \\
\text { membranes }\end{array}$ & $\mathrm{H}_{2}$ & $50 \mathrm{ppm}$ & Gas-phase NPs \\
\hline Arachchige/2018 [61] & $\begin{array}{c}\text { Au decorated } \mathrm{MoO}_{3} \\
\text { NFs }\end{array}$ & $\begin{array}{l}\mathrm{H}_{2} \mathrm{~S} \text {, acetone, } \\
\text { EtOH, } \mathrm{H}_{2}\end{array}$ & $\begin{array}{l}\text { ppb level, 5, 0.2, } 20 \\
\text { ppm (respectively) }\end{array}$ & Gas-phase NPs \\
\hline Xie et al./2018 [62] & Pd NPs on PET & $\mathrm{H}_{2}$ & $15 \mathrm{ppm}$ & Gas-phase NPs \\
\hline Koo et al./2019 [63] & $\begin{array}{l}\text { Pt decorated Al-doped } \\
\mathrm{ZnO}\end{array}$ & Acetone & $0.1 \mathrm{ppm}$ & Gas-phase NPs \\
\hline Chen et al./2020 [64] & $\begin{array}{c}\text { Au decorated, 3D } \\
\mathrm{MoS}_{2}\end{array}$ & TEA & $2 \mathrm{ppm}$ & Gas-phase NPs \\
\hline Sysoev et al./2009 [65] & $\mathrm{SnO}_{2} \mathrm{NPs} / \mathrm{NWs}$ & 2-Propanol & $1 \mathrm{ppm}$ & Gas-phase NPs \\
\hline Shaalan et al./2011 [66] & $\mathrm{SnO}_{2} \mathrm{NPs} / \mathrm{NWs} / \mathrm{MWs}$ & $\mathrm{NO}_{2}$ & $2 \mathrm{ppm}$ & Gas-phase NPs \\
\hline Bhatnagar et al./2017 [67] & $\mathrm{SnO}_{2} / \mathrm{SnO}_{2}: \mathrm{C} \mathrm{NPs}$ & $\mathrm{H}_{2}, \mathrm{EtOH}$ & $2 \%$ & Gas-phase NPs \\
\hline Vasiliev et al./2018 [68] & $\mathrm{SnO}_{2} \mathrm{NPs}$ & $\mathrm{H}_{2}$ & 20 ppm & Gas-phase NPs \\
\hline Skotadis et al. /2012 [29] & $\begin{array}{l}\text { Pt NPs with single } \\
\text { polymer coating }\end{array}$ & EtOH, R.H. & 500 ppm & Gas-phase NPs \\
\hline Skotadis et al. /2013 [71] & $\begin{array}{l}\text { Pt NPs with single } \\
\text { polymer coating }\end{array}$ & $\mathrm{EtOH}, \mathrm{RH}$ & 500 ppm & Gas-phase NPs \\
\hline Madianos et al./2018 [72] & $\begin{array}{l}\text { Pt NPs with four } \\
\text { polymer coatings }\end{array}$ & $\begin{array}{l}\text { Chlorpyrifos, } \\
\text { RH. }\end{array}$ & $\begin{array}{c}100 \mathrm{ppb} \\
\text { (chlorpyrifos) }\end{array}$ & Gas-phase NPs \\
\hline Skotadis et al. /2020 [73] & $\begin{array}{l}\text { Pt NPs with four } \\
\text { polymer coatings }\end{array}$ & $\begin{array}{c}\text { Chloract } 48 \text { EC, } \\
\text { RH }\end{array}$ & $\begin{array}{c}73.95 \mathrm{ppb} \\
\text { (chlorpyrifos) }\end{array}$ & Gas-phase NPs \\
\hline Afify et al./2015 [74] & $\begin{array}{l}\mathrm{W}^{4+} \mathrm{NPs} / \text { sepiolite } \\
\text { grains }\end{array}$ & $\mathrm{RH}$ & $40 \%$ & Precipitated NPs \\
\hline Hassan et al./2016 [75] & $\begin{array}{c}\mathrm{ZnO} \text { NPs/sepiolite } \\
\text { needles }\end{array}$ & $\begin{array}{c}\mathrm{RH}, \mathrm{NO}_{2} \text { and } \\
\mathrm{H}_{2}\end{array}$ & $\begin{array}{l}28 \% \text {, ppm levels, } 20 \\
\text { ppm }\end{array}$ & Precipitated NPs \\
\hline
\end{tabular}

In an effort to improve sensitivity and selectivity of multiply-networked p-type CuO nanowires (NWs), Lee et al. [42] functionalized NWs with heat-treated Au NPs of varying size. Heat treating thin, RF sputtered, metallic films, in a range usually between 400 and $500{ }^{\circ} \mathrm{C}$, is one of the most common methods for obtaining well-dispersed and uniform metallic NPs. By mainly changing the thickness of the initial metal layer, the NP size can be tuned. The heat-treatment approach has been followed by many other groups so as to functionalize metal oxides with NPs and in order to improve their, sensitivity, selectivity and reduce their operating temperature (from $150-400{ }^{\circ} \mathrm{C}$ ) to RT. It is worth noting that in most cases this two-step process that requires heating of the device at high temperatures, could be replaced by the 
single-step, RT gas-phase synthesis method. In any case, the use of high surface to volume materials such as NPs increases the active surface of the device by introducing additional catalysis sites. To be more specific, Kim et al. [43] have demonstrated improved sensitivity for toluene by modifying $\mathrm{SnO}_{2}$ nanofibres (NFs) using Pt NP layers of varying thickness; Wongrat et al. [44] employed $\mathrm{Au}$ NPs to improve the sensitivity of $\mathrm{ZnO}$ nanostructures towards ethanol detection; Choi et al. [45] modified single walled carbon nanotubes (SWCNTs) with Pt NPs for better sensitivity, recovery time and selectivity; Yang et al. [46] achieved better hydrogen detection by modifying $\mathrm{SnO}_{2}$ thin films on top of a $\mathrm{LiNbO}_{3}$ piezoelectric substrate with Pd NPs; Gasparotto et al. [47] improved the sensitivity of $\mathrm{ZnO}$ nanorods (NRs) towards $\mathrm{H}_{2}$ and $\mathrm{O}_{2}$ detection by decorating them with Au NPs; Liang et al. [48] employed Au-decorated $\mathrm{VO}_{2} \mathrm{NWs}$ of varying Au size and surface concentration to study their effect on sensitivity for $\mathrm{NO}_{2}$ detection; Drmosh et al. [49] deposited $\mathrm{Au} \mathrm{NPs}$ on $\mathrm{SnO}_{2}$ films for improved sensitivity, in $\mathrm{RT} \mathrm{NO}_{2}$ detection; Cao et al. [50] used Pd NPs decorated ZnO NRs, for improved ethanol detection at $260^{\circ} \mathrm{C}$, due to the catalytic behaviour of the Pd layer; Khalid et al. [51] decorated $\mathrm{SnO}_{2}$ NWs grown on quartz and silicon substrates with Au NPs for improved ethanol detection in RT. Finally, Jaiswal et al. [52] modified $\mathrm{MoS}_{2}$ with Pd NPs, for improved $\mathrm{H}_{2}$ sensitivity compared to pristine $\mathrm{MoS}_{2}$.

Reports on single-step, gas-phase synthesized NPs used in tandem with metal oxides are also abundant; the use of metal oxides, CNTs and 2D nanomaterials in tandem with catalytic noble metallic NPs, guarantees improved sensitivity, selectivity and operating temperature: Liang et al. [53] decorated $\mathrm{VO}_{2}$ nanosheets with Au NPs, achieving increased sensitivity for methane compared to untreated nanosheets; Yuan et al. [54] have functionalized tungsten oxide/porous silicon (PS) composites with Au NPs, achieving ppb levels of sensitivity in RT; Li et al. [55] deposited $\mathrm{Au}$ and $\mathrm{SnO}_{2} \mathrm{NPs}$ on the surface of $\mathrm{MoS}_{2}$ for triethylamine (TEA) detection, achieving better sensor properties compared to pristine $\mathrm{MoS}_{2}$; Hao et al. [56] decorated few-layered $\mathrm{MoS}_{2} / \mathrm{SiO}_{2} / \mathrm{Si}$ heterojunctions with Pd nanoparticles, increasing its sensitivity towards $\mathrm{H}_{2}$ by optimizing Pd thickness; Vernieres et al. [57] fabricated Fe Nanocubes for $\mathrm{NO}_{2}$ detection, this yielded ppb level sensitivity by operating the device on a micro-hotplate; Dhall et al. [58] introduced Pt NPs in a MWCNTs/TiO 2 hybrid material, thus achieving improved sensitivity towards $\mathrm{H}_{2}$ in RT; Song et al. [59] decorated $\mathrm{ZnO}$ nanorods grown directly on flat $\mathrm{Al}_{2} \mathrm{O}_{3}$ ceramic electrodes with $\mathrm{Au}$ NPs, for the successful detection of TEA in close to RT conditions $\left(40^{\circ} \mathrm{C}\right)$ and for a relative humidity (RH) of $30 \%$. Chen et al. [60] coated PMMA membranes with Pd NPs to fabricate a $\mathrm{H}_{2}$ sensor that has a tunable sensitivity; the sensor can be optimized by tuning the thickness of the PMMA layer and NP size. Arachchige et al. [61] decorated molybdenum trioxide $\left(\mathrm{MoO}_{3}\right) \mathrm{NFs}$ with Au NPs towards the detection of $\mathrm{H}_{2} \mathrm{~S}$, acetone, $\mathrm{EtOH}$ and $\mathrm{H}_{2}$ gases; the sensor showed increased sensitivity (10 times higher) if compared to pristine $\mathrm{MoO}_{3}$. Xie et al. [62] fabricated an optically transparent and flexible $\mathrm{H}_{2}$ sensor based on Pd NPs on top of a polyethylene terephthalate (PET) sheet; the sensor was evaluated under bending and was able to operate in a wide range of R.H. Koo et al. [63] reported on Pt-decorated Al-doped ZnO (Pt-AZO) NPs for optimized acetone detection; the Pt catalytic effect leads to an increase of absorbed oxygen ion species on the material's surface. Chen et al. [64] deposited Au nanoparticles on the surface of $3 \mathrm{D} \mathrm{MoS}$ nanostructures, previously grown on top of $\mathrm{Al}_{2} \mathrm{O}_{3}$ tubular nanostructures, thus fabricating a TEA gas sensor.

Bare (without any decoration) metal-oxide NPs have been also used as chemical sensors. Sysoev et al. [65] used pristine $\mathrm{SnO}_{2} \mathrm{NPs}$ as well as $\mathrm{SnO}_{2}$ nanowires (NWs), for the detection of 2-propanol; the NW networks have been found to show better stability as well as sensitivity. Shaalan et al. [66] fabricated $\mathrm{SnO}_{2} \mathrm{NP}$ films, micro-wires (MWs) as well NWs, in order to compare their response towards $\mathrm{NO}_{2}$ vapours. In all cases the operating temperature range of the device was from $\mathrm{RT}$ to $300{ }^{\circ} \mathrm{C}$, with peak sensitivity at $150 \mathrm{~V}$ for the NWs sensor; the NW sensor outperformed other sensor types due its reduced inter-grain boundaries density. Bhatnagar et al. [67] used pristine $\mathrm{SnO}_{2} \mathrm{NPs}$ as well as $\mathrm{SnO}_{2}: \mathrm{C} \mathrm{NP}$ alloys, to improve the sensor's selectivity towards $\mathrm{H}_{2}$ and $\mathrm{EtOH}$ (both reducing gases) detection; the sensors operated in a wide temperature range namely: RT $-210{ }^{\circ} \mathrm{C}$. Vasiliev et al. [68] used the spark-discharge method to prepare $\mathrm{SnO}_{2} \mathrm{NPs}$; this "dry" NP synthesis method reduces 
the hydroxyl concentration on the NP surface, rendering the sensor lees sensitive to any changes in ambient humidity.

In a different approach, other research groups aim to tune the inter-NP distance of the NP layer while the sensor is exposed to volatile organic compounds (VOCs). This transduction process takes advantage of sputtering's ability to produce 2-D, gas-phase, self-assembled NP films of varying surface-coverage, in a repeatable and controllable manner. As a result of this process, devices that lie just below the percolation threshold present conductivity that is governed from quantum charge-transport mechanisms such as tunneling, hopping etc. This renders the devices extremely sensitive in any change in the inter-NP distance. Based on their original experience regarding the production of fully ink-jet printed chemical sensors [69,70], Skotadis et al. [29] combined gas-phase, DC sputtered Pt NP films, with polymer coatings in order to produce gas-sensitive devices (Figure 3). The polymer coatings act as the gas sensitive layer of the device, absorbing many of the VOCs surrounding the sensor. This translates in an increase of device resistance since the swelling of the polymer layer leads to the deformation of the underlying NP film and in an increase in inter-NP distance; the sensing mechanism for this type of devices can be explained by the discussion found in Section 3.1. The Pt NP films were of varying surface coverage, to optimize the sensor according to the NPs distribution. Additionally, the authors have demonstrated the successful implementation of this sensor on top of a flexible polyimide substrate [71]. In an effort to detect and identify pesticide vapours, Madianos et al. [72] improved the previously reported device architecture by incorporating three additional and distinctive polymer coatings. This improves the selectivity of the sensing array and in combination with statistical analysis methods such as principal component analysis (PCA), the device ultimately identified between pesticide vapours (chlorpyrifos) and RH. In a 2020 publication, Skotadis et al. [73] have used a similar device architecture to identify between a commercially available pesticide, namely Chloract 48 EC (a chlorpyrifos-based pesticide), and RH (Figure 4). Finally, in two publications by Afify et al. [74] and Hassan et al. [75], non-traditional materials such as sepiolite grains and needles decorated by NPs, have been employed as chemical sensors. In [74], various oxide/hydroxide NPs have precipitated on top of sepiolite grains; pellets of the respective material combined with tungsten NPs exhibited the best behaviour as humidity sensors, operating at RT. In [75] ZnO NPs have precipitated on top of sepiolite needles, towards their implementation as humidity, $\mathrm{NO}_{2}$ and $\mathrm{H}_{2}$ chemical sensors, operating at an optimal temperature of $300^{\circ} \mathrm{C}$.

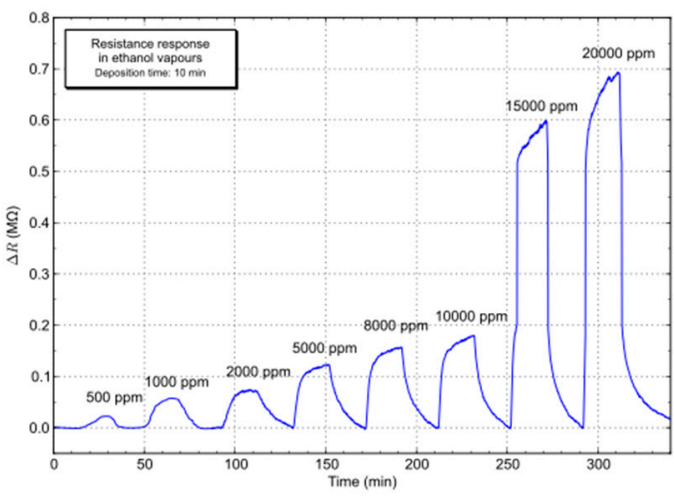

(a)

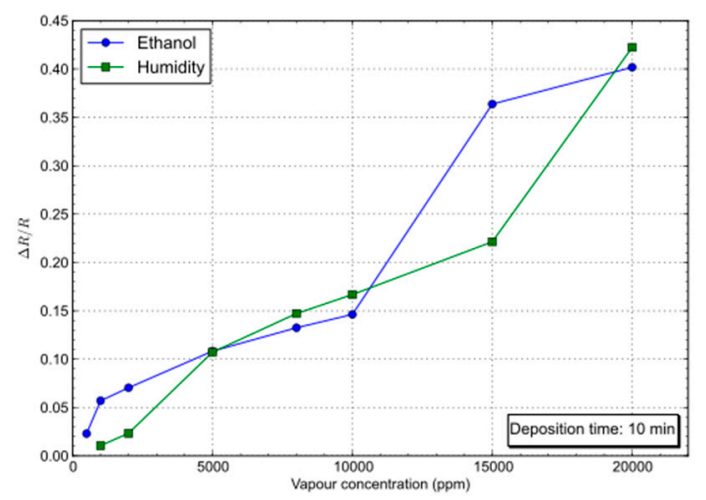

(b)

Figure 3. (a) Transient resistance response to humidity, for a hybrid Pt NP/polymer chemical-sensor, realized after a nanoparticle deposition of $10 \mathrm{~min}$ in ethanol (b). Relative resistance response of the same sensor in humidity and ethanol. Reprinted from [29], with permission from Elsevier. 

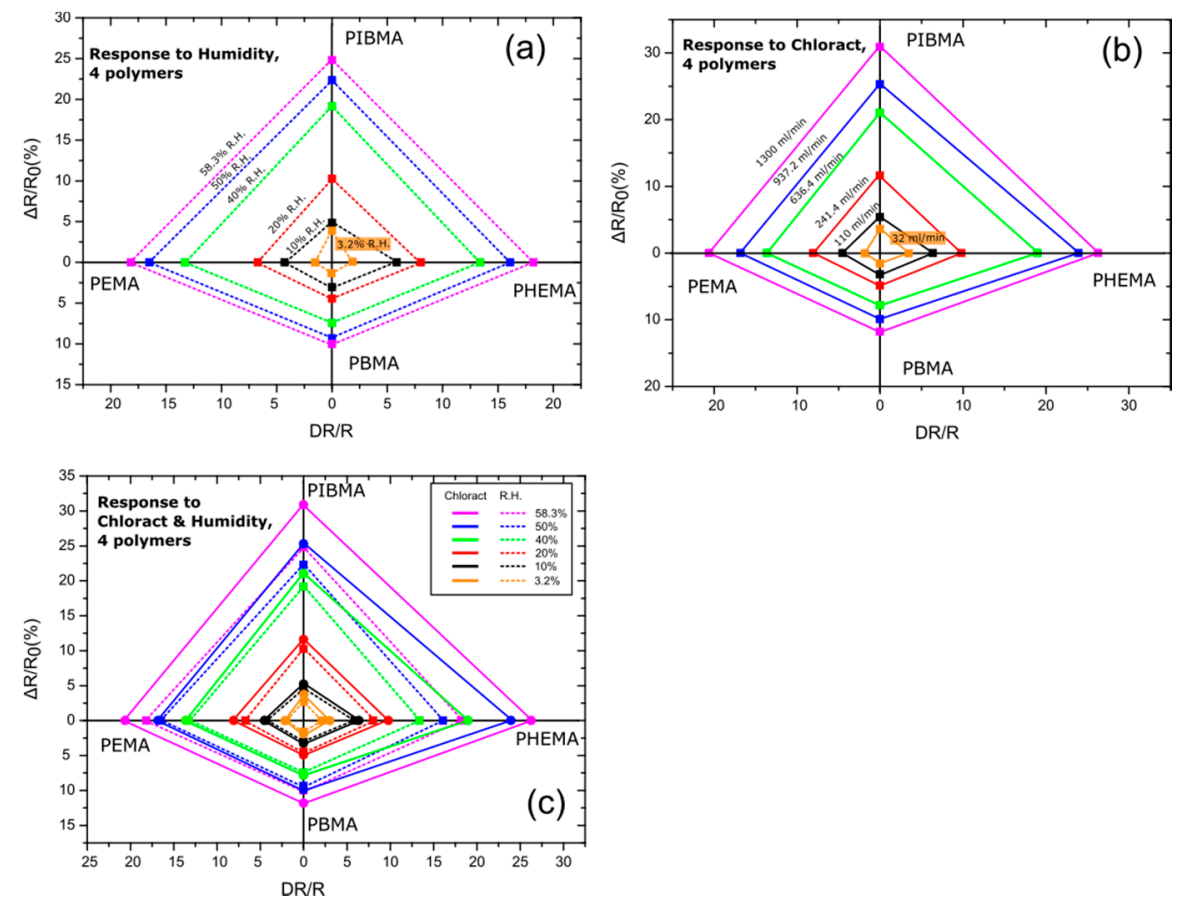

Figure 4. Distinctive fingerprint-patterns after the response of hybrid Pt NPs/polymer based sensors with all four different polymeric coatings towards (a) relative humidity ( $\mathrm{RH}$ ) from $3.2 \%$ to $58.3 \%$ (b) Chloract test-solution, for $\mathrm{N}_{2}$ carrier-gas flows from 32 to $1300 \mathrm{~mL} / \mathrm{min}$ (identical $\mathrm{N}_{2}$ flows with the ones used to achieve R.H. from $3.2 \%$ to $58.3 \%$ ) and (c) combined response to both analytes. Reprinted from [73], with permission from Elsevier.

\section{Biosensing Devices}

In the final part of this review, biosensing devices based on gas-phase NPs will be discussed. As in the case of chemical sensors, varying materials such as metal oxides, 2D materials etc. have been also combined with catalytic NPs in order to produce biosensing devices. High aspect ratio and catalytic properties of noble gas-phase NPs are again prominent; it is worth noting that in the case of biosensors, NPs prove to be an exceptional anchoring site for the immobilization of critical materials. All results discussed in the current section are summarized in Table 3.

Hou et al. [76] have reported on $\mathrm{ZnO}$ nanorods decorated with Au NPs (ZnO NRs-Au NPs) hybrids, without the addition of any surfactant or reducing agent, for the electrochemical detection of ascorbic acid and uric acid (cancer biomarkers); the Influence of Au NP size and density has been also studied. Li et al. [77] have prepared a disposable electrochemical sensor for the determination of bisphenol A (an endocrine disruptor); the sensor was fabricated by depositing Au NPs on paper and then modifying them with MWCNTs. Skotadis et al. [78] prepared a network of 2D, self-assembled Pt NPs for the detection of DNA hybridization events (even for single base-pair mismatch); hybridized DNA acts as a molecular conductive-bridging between NPs, enhancing conductivity (Figure 5). By modifying the inter-particle distance (controlled via the sputtering deposition time) device sensitivity was optimized. Yuan et al. [79] modified chemical vapour deposition (CVD)-grown graphene (GN) with gas-phase Pt NPs on top of a glassy carbon electrode and without the need for GN transfer; the well-exposed active PT catalyst sites, showed advantages in $\mathrm{H}_{2} \mathrm{O}_{2}$ detection. In a second article by Yuan et al. [80], the development of CVD grown monolayer GN (on top of glassy carbon) decorated with $\mathrm{Au}$ NPs was discussed. The paper reports on the amperometric and non-enzymatic determination of $\mathrm{H}_{2} \mathrm{O}_{2}$ and avoids any NP contamination due to the transfer-free fabrication process. In a 2017 article, Skotadis et al. [81] prepared an environmental sensor for $\mathrm{Pb}^{2+}$ detection in water; the sensor utilizes DNAzymes' disassociation in the presence of $\mathrm{Pb}^{2+}$ ions, resulting in a drop of conductivity. Galdino et al. [82] prepared a colorimetric biosensor for total cholesterol detection by using Ionic liquid 
(IL)-functionalized graphene oxide (GO), combined with cholesterol oxidase and decorated with $\mathrm{Au}$ NPs. The use of gas-phase NPs prevents the undesired by-products and remaining ligands that are always present after chemical NP synthesis. Gasparotto et al. [83] used ZnO NRs decorated by $\mathrm{Au}$ NPs, for the electrochemical detection of the ovarian cancer antigen CA-125/MUC126. The Au NPs provide a favourable platform for efficient loading of anti-CA-125 antibody via binding with cystamine and glutaraldehyde (observed by SEM images); the reported limit of detection (LOD) is 100 times lower than a standard immunoblot system. Madianos et al. [84,85] reported on two different configurations for pesticide detection, by immobilizing appropriate aptamers for pesticide capturing on top of Pt NPs. At first, the authors fabricated Pt NP microwires by employing e-beam lithography and DC sputtering; in a follow-up publication the authors fabricated 2D NP networks (less complicated fabrication approach). In both cases target capturing leads in a shift in the sensor's impedance. Biasotto et al. [86] used ZnO NRs modified with gas-phase Au NPs, for efficient Hepatitis $\mathrm{C}$ Virus detection. Au was used for critical anti-HCV antibodies-capturing (by coating the $\mathrm{Au} / \mathrm{ZnO}$ structure with cystamine and glutaraldehyde). Danielson et al. [87] used Au NPs as anchoring sites for biomolecules (streptavidin and DNA) in ZnO NWs. In 2020 Danielson et al. [88] modified GN surfaces using gas-phase Au NPs so as to facilitate the attachment and binding of a DNA aptamer. The sensor operates as a FET and is capable of detecting DNA hybridization events as well as the protein streptavidin. Della Ventura et al. [89] have used the laser-ablation technique (using fs laser pulses) for Au NPs preparation, in order to enhance the sensitivity of a quartz crystal microbalance electrode. The authors have optimized the sensor based on NP surface coverage by successfully detecting antibody-antigen interactions, increasing by 4 times the response of the sensor if compared to a bare QCM electrode.

Table 3. Gas-phase NP biosensors.

\begin{tabular}{|c|c|c|c|c|}
\hline Authors/Year [Ref] & Active Material & Target Type & $\begin{array}{c}\text { LoD } \\
\text { (Concentration) }\end{array}$ & Notes \\
\hline Hou et al./2016 [76] & Au decorated $\mathrm{ZnO}$ NRs & $\begin{array}{l}\text { ascorbic acid, uric } \\
\text { acid }\end{array}$ & $\begin{array}{l}0.1 \mathrm{mM}, 0.01 \mathrm{mM} \\
\text { (respectively) }\end{array}$ & Gas-phase NPs \\
\hline Li et al./2016 [77] & Au decorated MWCNTs & bisphenol A & $0.03 \mathrm{mg} / \mathrm{L}$ & $\begin{array}{c}\text { Gas-phase NPs \& } \\
\text { paper substrate }\end{array}$ \\
\hline Skotadis et al./2016 [78] & Pt NPs-2D films & DNA hybridization & $1 \mathrm{nM}$ & Gas-phase NPs \\
\hline Yuan et al./2017 [79] & Pt decorated graphene & $\mathrm{H}_{2} \mathrm{O}_{2}$ & $0.18 \mathrm{nM}$ & Gas-phase NPs \\
\hline Yuan et al./2017 [80] & Au decorated graphene & $\mathrm{H}_{2} \mathrm{O}_{2}$ & $10 \mathrm{nM}$ & Gas-phase NPs \\
\hline Skotadis et al./2017 [81] & Pt NPs-2D films & $\mathrm{Pb}^{2+}$ ions & $10 \mathrm{nM}$ & Gas-phase NPs \\
\hline Galdino et al./2017 [82] & $\begin{array}{l}\text { Au decorated Graphene } \\
\text { Oxide }\end{array}$ & Total Cholesterol & $25 \mu \mathrm{mol} / \mathrm{L}$ & Gas-phase NPs \\
\hline Gasparotto et al./2017 [83] & Au decorated $\mathrm{ZnO}$ NRs & $\begin{array}{c}\text { antigen } \\
\text { CA-125/MUC126 }\end{array}$ & $2.5 \mathrm{ng} / \mu \mathrm{L}$ & Gas-phase NPs \\
\hline Madianos et al./2018 [84] & Pt NP microwires & $\begin{array}{l}\text { Acetamiprid, } \\
\text { atrazine }\end{array}$ & $\begin{array}{l}1 \mathrm{pM}, 10 \mathrm{pM} \\
\text { (respectively) }\end{array}$ & Gas-phase NPs \\
\hline Madianos et al./2018 [85] & Pt NPs-2D films & $\begin{array}{l}\text { Acetamiprid, } \\
\text { atrazine }\end{array}$ & $\begin{array}{l}6 \mathrm{pM}, 40 \mathrm{pM} \\
\text { (respectively) }\end{array}$ & Gas-phase NPs \\
\hline Biasotto et al./2019 [86] & Au decorated $\mathrm{ZnO}$ NRs & Hep. C Virus & $0.25 \mu \mathrm{g} / \mu \mathrm{L}$ & Gas-phase NPs \\
\hline Danielson et al./2019 [87] & Au decorated $\mathrm{ZnO}$ NWs & $\begin{array}{c}\text { DNA } \\
\text { hybridization, } \\
\text { streptavidin } \\
\text { DNA }\end{array}$ & $\begin{array}{c}100 \mathrm{pM}, 10 \mathrm{nM} \\
\text { (respectively) }\end{array}$ & Gas-phase NPs \\
\hline Danielson et al./2020 [88] & Au decorated graphene & $\begin{array}{l}\text { hybridization, } \\
\text { streptavidin }\end{array}$ & $15 \mathrm{aM}$ & Gas-phase NPs \\
\hline Della Ventura et al. [89] & $\mathrm{Au}$ NPs & IgG antigen & $25 \mu \mathrm{g} / \mathrm{mL}$ & Laser-ablated NPs \\
\hline Said et al./2017 [90] & $\begin{array}{l}\mathrm{Ag} / \mathrm{Cu} \text { decorated } \\
\text { graphene FETs }\end{array}$ & Glucose & $1 \mu \mathrm{M}$ & Gas-phase NPs \\
\hline Jung et al./2018 [91] & $\begin{array}{c}\mathrm{NiO} \text { decorated } \mathrm{ZnO} \text { NRs } \\
\text { FETs }\end{array}$ & Glucose & $0.001 \mathrm{mM}$ & Gas-phase NPs \\
\hline Soganci et.al./2018 [92] & Cu decorated graphene & Glucose & $0.01 \mathrm{mM}$ & Gas-phase NPs \\
\hline Olejnik et al./2020 [93] & Au decorated $\mathrm{Ti}$ & Glucose & $30 \mu \mathrm{M}$ & Heat-treated NPs \\
\hline Zhang et al. 2020 [94] & Au decorated electrodes & Glucose & $1 \mu \mathrm{M}$ & Gas-phase NPs \\
\hline Soganci et.al./2020 [95] & $\begin{array}{l}\text { Cu NPs/graphene, } \\
\text { sandwiched structure }\end{array}$ & Glucose & $0.025 \mu \mathrm{M}$ & Gas-phase NPs \\
\hline
\end{tabular}




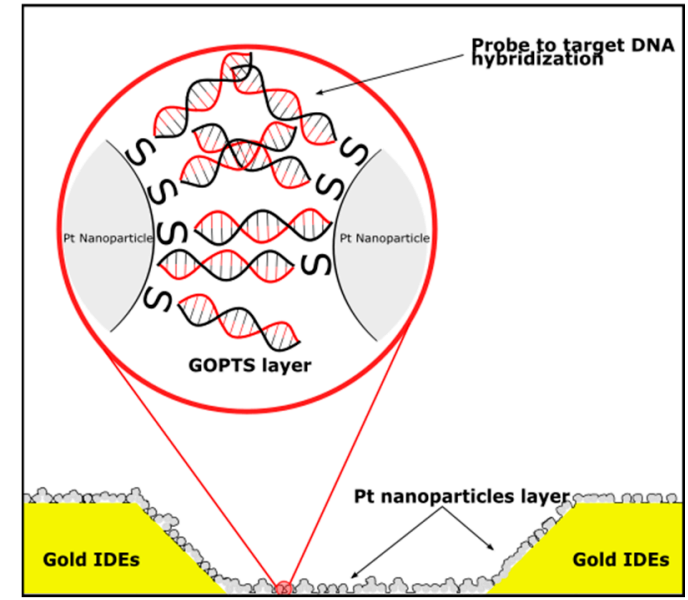

(a)

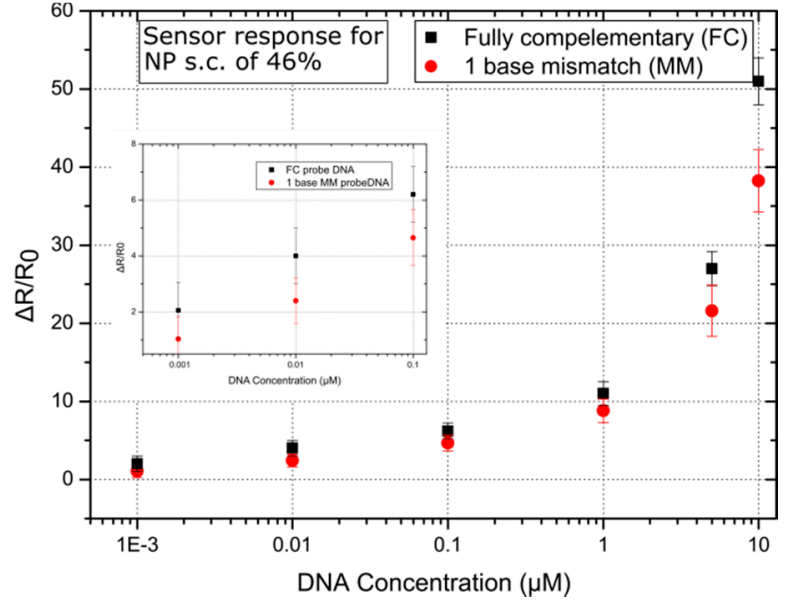

(b)

Figure 5. (a) Cross section of the Pt NP sensing device (schematic) for DNA hybridization detection, after the target to probe DNA hybridization event (b) Sensor response (nanoparticle surface coverage: $46 \%$, IDE gap: $5 \mu \mathrm{m}$ ) for fully complementary (FC) probe to target DNA and single base pair mismatched (1 base MM) probe to target DNA hybridization, in a logarithmic scale. Reprinted from [78], with permission from Elsevier.

It is worth noting that there are many reports focusing on the detection of glucose. If the fact that $20 \%$ of the world population suffers from diabetes is taken into account, the importance of fast, selective, portable, low-power, low-cost and accurate glucose sensors is more than obvious. Many efforts focus on the detection of glucose oxide (enzymatic approach) while others focus on its non-enzymatic detection (avoiding expensive and without long-term stability enzymes). Said et al. [90] prepared Graphite-oxide based field-effect transistors (FETs) whose sensitivity was improved by incorporating $\mathrm{Ag}$ and $\mathrm{Cu}$ NPs on a non-enzymatic sensor. Jung et al. [91] prepared a nonenzymatic flexible FET based glucose sensor using nickel oxide NPs (NiO)-modified zinc oxide nanorods ( $\mathrm{ZnO} \mathrm{NRs).} \mathrm{It} \mathrm{is} \mathrm{worth} \mathrm{noting}$ that the sensor was tried in human blood samples measuring glucose efficiently. Soganci et.al. [92] used a GN film prepared by CVD and transferred to FTO glass; the film was then functionalized using $\mathrm{Cu}$ NPs, producing a non-enzymatic sensor. Olejnik et al. [93] presented a flexible and enzyme-free electrochemical biosensor based on the combination of Ti and Au NPs, modified by a perm-selective Nafion membrane so as to improve selectivity. Zhang et al. [94] covered two electrode materials ( $\mathrm{Au}$ and conductive carbon) with $3.4 \mathrm{~nm}$ in width Au NPs for the preparation of an enzymatic electrochemical biosensor; the effect of Au NP aerial density was studied by modifying sputtering time. Soganci et.al. [95] in a 2020 article presented a non-enzymatic biosensor based on $\mathrm{Cu}$ NPs "sandwiched" between two single GN layers. The unique sandwich structure, presented increased sensitivity if compared to single layer GN decorated NPs; its stability, sensitivity and response time were improved, in accordance with previous theoretical studies, due to the protection of the NP layer by the sandwich structure.

\section{Conclusions}

A comprehensive review on recent advances of gas-phase synthesized NP-based sensors has been conducted, focusing on strain-sensors, chemical sensors and biological sensors. The flexibility offered by gas-phase synthesis methods offers unique advantages in the development and optimization of nanomaterial-based sensing systems. Simple operation, low-cost, batch fabrication, facile control over many critical device parameters (e.g., NP size and distribution/density), easy material combination for the production of nanoheterostructures, easy integration of biomaterials and their room temperature operation are but a few of their advantages. In addition, the avoidance of any complex chemical processes for the fabrication as well as functionalization of NPs, leaves the surface free of any 
contaminants and chemical reagent residues; this proves to be critical in many of the aforementioned sensing applications.

If the typical advantages of NPs are additionally taken into account (high surface to volume ratio, catalytic activity, tunable size, tunable device conductivity that often relies on quantum charge transport phenomena, size comparable to that of many biomaterials etc.), the gas-phase synthesis of NPs emerges as a powerful and enabling technology that even years after its initial implementation, still manages to push the boundaries in many and diverse scientific fields. The future prospects of the gas-phase technique remain optimistic since it emerges as the most promising candidate for easy and trouble-free integration in mass-production processes. It is worth noting that especially sputtering has both a significant tradition as well as a strong presence in today's microelectronics industry. Competing techniques such as chemical or especially green synthesis of NPs have yet to establish themselves as suitable and more favourable alternatives for the batch-fabrication of nanoparticle-based devices. Finally, strain-sensors produced via gas-phase synthesis techniques feature enhanced sensitivity when compared to competing techniques. This is partly owed to the technique's flexibility as well as its easy combination with various thin-film deposition methods for the production of extremely sensitive devices. Such results could be easily applied in other sensing applications (e.g., chemical sensors etc.), highlighting the technique's ability to produce advanced and efficient sensing devices.

Author Contributions: E.S. has conducted an overview of recent research papers related to chemical, strain and bio sensors based on Gas-phase synthesized nanoparticles. He has authored/drafted the paper and has also prepared all Figures, Tables etc. E.A. has contributed in finding available papers related to strain sensors. M.K. has contributed in finding available papers related to bio-sensors. D.T. copyedited the paper and has contributed in its structure, scope and purpose as well as in finding specific publications. All authors have read and agreed to the published version of the manuscript.

Funding: This research received no external funding.

Conflicts of Interest: The authors declare no conflict of interest.

\section{References}

1. Majidinia, M.; Mirza-Aghazadeh-Attari, M.; Rahimi, M.; Safa, A.; Yousefi, B. Overcoming multidrug resistance in cancer: Recent progress in nanotechnology and new horizons. IUBMB Life 2020, 72, 855-871. [CrossRef]

2. Niemeyer, C.M. Nanoparticles, proteins, and nucleic acids: Biotechnology meets materials science. Angew. Chem. Int. 2001, 40, 4128-4158. [CrossRef]

3. Hajipour, M.J.; Fromm, K.M.; Ashkarran, A.A.; De Aberasturi, D.J.; De Larramendi, I.R.; Rojo, T. Antibacterial properties of nanoparticles. Trends Biotechnol. 2012, 30, 1-13. [CrossRef] [PubMed]

4. Gangopadhyay, R.; De, A. Conducting polymer nanocomposites: A brief overview. Chem. Mater. 2000, 12, 608-622. [CrossRef]

5. Wang, S.; Lin, L.; Wang, Z.L. Triboelectric nanogenerators as self-powered active sensors. Nano Energy 2015, 11, 436-462. [CrossRef]

6. Ali, I. New generation adsorbents for water treatment. Chem. Rev. 2012, 112, 5073-5091. [CrossRef] [PubMed]

7. Anker, J.N.; Hall, W.P.; Lyandres, O.; Shah, N.C.; Zhao, J.; Van Duyne, R.P. Biosensing with plasmonic nanosensors. Nat. Mater. 2008, 7, 442-453. [CrossRef]

8. Gordon, R. Nanostructured metals for light-based technologies. Nanotechnology 2019, 30, 212001. [CrossRef]

9. Rai, M.; Yadav, A.; Gade, A. Silver nanoparticles as a new generation of antimicrobials. Biotechnol. Adv. 2009, 27, 76-83. [CrossRef] [PubMed]

10. Saha, K.; Agasti, S.S.; Kim, C.; Li, X.; Rotello, V.M. Gold nanoparticles in chemical and biological sensing. Chem. Rev. 2012, 112, 2739-2779. [CrossRef]

11. Astruc, D.; Lu, F.; Aranzaes, J.R. Nanoparticles as recyclable catalysts: The frontier between homogeneous and heterogeneous catalysis. Angew. Chem. Int. 2005, 44, 7852-7872. [CrossRef]

12. Ghosh, P.; Gang, G.; DE, M.; Kim, C.K.; Rotello, V.M. Gold nanoparticles in delivery applications. Adv. Drug Deliv. Rev. 2008, 60, 1307-1315. [CrossRef] [PubMed] 
13. Sun, C.; Lee, J.S.H.; Zhang, M. Magnetic nanoparticles in MR imaging and drug delivery. Adv. Drug Deliv. Rev. 2008, 60, 1252-1265. [CrossRef] [PubMed]

14. Maake, P.J.; Bolokang, A.S.; Arendse, C.J.; Iwuoha, E.I.; Motaung, D.E. Metal oxides and noble metals application in organic solar cells. Sol. Energy 2020, 207, 347-366. [CrossRef]

15. Patnaik, S.; Sahoo, D.P.; Parida, K. An overview on Ag modified g-C3N4 based nanostructured materials for energy and environmental applications. Renew. Sust. Energ. Rev. 2018, 82, 1297-1312. [CrossRef]

16. Durán, N.; Seabra, A.B. Biogenic synthesized Ag/Au nanoparticles: Production, characterization, and applications. Curr. Nanosci. 2018, 14, 82-94. [CrossRef]

17. Ibañez, F.J.; Zamborini, F.P. Chemiresistive sensing with chemically modified metal and alloy nanoparticles. Small 2012, 8, 174-202. [CrossRef] [PubMed]

18. Mahmoud, M.A.; O'Neil, D.; El-Sayed, M.A. Hollow and solid metallic nanoparticles in sensing and in nanocatalysis. Chem. Mater 2014, 26, 44-58. [CrossRef]

19. Cho, I.-H.; Kim, D.H.; Park, S. Electrochemical biosensors: Perspective on functional nanomaterials for on-site analysis. Biomater. Res. 2020, 24, 1-12. [CrossRef] [PubMed]

20. Alafeef, M.; Moitra, P.; Pan, D. Nano-enabled sensing approaches for pathogenic bacterial detection. Biosens. Bioelectron. 2020, 165, 112276. [CrossRef] [PubMed]

21. Liu, B.; Zhuang, J.; Wei, G. Recent advances in the design of colorimetric sensors for environmental monitoring. Environ. Sci. 2020, 7, 2195-2213. [CrossRef]

22. He, S.; Yuan, Y.; Nag, A.; Mukhopadhyay, S.C.; Organ, D.R. A review on the use of impedimetric sensors for the inspection of food quality. Int. J. Environ. Res. Public Health 2020, 17, 5220. [CrossRef]

23. Wang, B.; Facchetti, A. Mechanically Flexible Conductors for Stretchable and Wearable E-Skin and E-Textile Devices. Adv. Mater. 2019, 31, 1901408. [CrossRef]

24. Grammatikopoulos, P.; Steinhauer, S.; Vernieres, J.; Singh, V.; Sowwan, M. Nanoparticle design by gas-phase synthesis. Adv. Phys. X 2016, 1, 81-100. [CrossRef]

25. Xia, Y.; Xiong, Y.; Lim, B.; Skrabalak, S.E. Shape-controlled synthesis of metal nanocrystals: Simple chemistry meets complex physics? Angew. Chem. Int. 2009, 48, 60-103. [CrossRef]

26. Cozzoli, P.D.; Manna, L. Synthetic strategies to size and shape controlled nanocrystals and nanocrystal Heterostructures. In Bio-Applications of Nanoparticles, 1st ed.; Chan, W.C.W., Ed.; Springer: New York, NY, USA, 2007; Volume 62, pp. 1-14.

27. Schröfel, A.; Kratošová, G.; Šafařík, I.; Raška, I.; Shor, L.M. Applications of biosynthesized metallic nanoparticles-A review. Acta Biomater. 2014, 10, 4023-4042. [CrossRef]

28. Rana, A.; Yadav, K.; Jagadevan, S. A comprehensive review on green synthesis of nature-inspired metal nanoparticles: Mechanism, application and toxicity. J. Clean. Prod. 2020, 272, 122880. [CrossRef]

29. Skotadis, E.; Tanner, J.L.; Stathopoulos, S.; Tsouti, V.; Tsoukalas, D. Chemical sensing based on double layer PHEMA polymer and platinum nanoparticle films. Sens. Actuators B Chem. 2012, 175, 85-91. [CrossRef]

30. Herrmann, J.; Müller, K.H.; Reda, T.; Baxter, G.R.; Raguse, B.D.; De Groot, G.J.; Chai, R.; Roberts, M.; Wieczorek, L. Nanoparticle films as sensitive strain gauges. Appl. Phys. Lett. 2007, 91, 183105. [CrossRef]

31. Aslanidis, E.; Skotadis, E.; Moutoulas, E.; Tsoukalas, D. Thin film protected flexible nanoparticle strain sensors: Experiments and modelling. Sensors 2020, 20, 2584. [CrossRef]

32. Tanner, J.L.; Mousadakos, D.; Giannakopoulos, K.; Skotadis, E.; Tsoukalas, D. High strain sensitivity controlled by the surface density of platinum nanoparticles. Nanotechnology 2012, 23, 285501. [CrossRef]

33. Zheng, M.; Li, W.; Xu, M.; Han, M.; Xie, B. Strain sensors based on chromium nanoparticle arrays. Nanoscale 2014, 6, 3930-3933. [CrossRef]

34. Xie, B.; Mao, P.; Chen, M.; Liu, J.M.; Wang, G. A tunable palladium nanoparticle film-based strain sensor in a Mott variable-range hopping regime. Sens. Actuat. A Phys. 2018, 272, 161-169. [CrossRef]

35. Patsiouras, L.; Skotadis, E.; Gialama, N.; Giannakopoulos, K.; Tsoukalas, D. Atomic layer deposited $\mathrm{Al} 2 \mathrm{O} 3$ thin films as humidity barrier coatings for nanoparticle-based strain sensors. Nanotechnology 2018, 29, 465706. [CrossRef]

36. Schwebke, S.; Winter, S.; Koch, M.; Schultes, G. Piezoresistive granular metal thin films of platinum-boron nitride and platinum-alumina at higher strain levels. J. Appl. Phys. 2018, 124, 235308. [CrossRef]

37. Min, S.H.; Lee, G.Y.; Ahn, S.H. Direct printing of highly sensitive, stretchable, and durable strain sensor based on silver nanoparticles/multi-walled carbon nanotubes composites. Compos. B. Eng. 2019, 161, 395-401. [CrossRef] 
38. Lee, G.Y.; Kim, M.S.; Min, S.H.; Ihn, J.B.; Ahn, S.H. Highly Sensitive Solvent-free Silver Nanoparticle Strain Sensors with Tunable Sensitivity Created Using an Aerodynamically Focused Nanoparticle Printer. ACS Appl. Mater. Interfaces 2019, 11, 26421-26432. [CrossRef] [PubMed]

39. Liu, F.; Shao, W.; Xu, G.; Yuan, L. Response characteristics of strain sensors based on closely spaced nanocluster films with controlled coverage. Chin. J. Chem. Phys. 2019, 32, 213-217. [CrossRef]

40. Chen, M.; Luo, W.; Xu, Z.; Wang, G.; Han, M. An ultrahigh resolution pressure sensor based on percolative metal nanoparticle arrays. Nat. Commun. 2019, 10, 4024. [CrossRef]

41. Zhang, W.; Li, J.; Lei, H.; Li, B. Plasmon-Induced Selective Enhancement of Green Emission in Lanthanide-Doped Nanoparticles. ACS Appl. Mater. Interfaces 2017, 9, 42935-42942. [CrossRef]

42. Lee, J.S.; Katoch, A.; Kim, J.H.; Kim, S.S. Effect of Au nanoparticle size on the gas-sensing performance of p-CuO nanowires. Sens. Actuat. B Chem. 2016, 222, 307-314. [CrossRef]

43. Kim, J.H.; Abideen, Z.U.; Zheng, Y.; Kim, S.S. Improvement of toluene-sensing performance of $\mathrm{SnO}_{2}$ nanofibers by pt functionalization. Sensors 2016, 16, 1857. [CrossRef]

44. Wongrat, E.; Chanlek, N.; Chueaiarrom, C.; Hongsith, N.; Choopun, S. Low temperature ethanol response enhancement of $\mathrm{ZnO}$ nanostructures sensor decorated with gold nanoparticles exposed to UV illumination. Sens. Actuat. A Phys. 2016, 251, 188-197. [CrossRef]

45. Choi, S.W.; Kim, J.; Byun, Y.T. Highly sensitive and selective $\mathrm{NO}_{2}$ detection by Pt nanoparticles-decorated single-walled carbon nanotubes and the underlying sensing mechanism. Sens. Actuat. B Chem. 2017, 238, 1032-1042. [CrossRef]

46. Yang, L.; Yin, C.; Zhang, Z.; Zhou, J.; Xu, H. The investigation of hydrogen gas sensing properties of SAW gas sensor based on palladium surface modified $\mathrm{SnO}_{2}$ thin film. Mater. Sci. Semicond. Process. 2017, 60, 16-28. [CrossRef]

47. Gasparotto, G.; Da Silva, R.A.; Zaghete, M.A.; Perazolli, L.A.; Mazon, T. Novel route for fabrication of ZnO nanorods-Au nanoparticles hybrids directly supported on substrate and their application as gas sensors. Mater. Res. 2018, 21, 20170796. [CrossRef]

48. Liang, J.; Zhu, K.; Yang, R.; Hu, M. Room temperature $\mathrm{NO}_{2}$ sensing properties of Au-decorated vanadium oxide nanowires sensor. Ceram. Int. 2018, 44, 2261-2268. [CrossRef]

49. Drmosh, Q.A.; Yamani, Z.H.; Mohamedkhair, A.K.; Hossain, M.K.; Ibrahim, A. Gold nanoparticles incorporated $\mathrm{SnO}_{2}$ thin film: Highly responsive and selective detection of $\mathrm{NO}_{2}$ at room temperature. Mat. Lett. 2018, 214, 283-286. [CrossRef]

50. Cao, P.; Yang, Z.; Navale, S.T.; Stadler, F.J.; Zhu, D. Ethanol sensing behavior of Pd-nanoparticles decorated ZnO-nanorod based chemiresistive gas sensors. Sens. Actuators B Chem. 2019, 298, 126850. [CrossRef]

51. Wafaa Khalid, K.; Ali Abadi, A.; Abdulqader Dawood, F. Synthesis of $\mathrm{SnO}_{2}$ Nanowires on Quartz and Silicon Substrates for Gas Sensors. J. Inorg. Organomet. Polym. 2020, 30, 3294-3304. [CrossRef]

52. Jaiswal, J.; Tiwari, P.; Singh, P.; Chandra, R. Fabrication of highly responsive room temperature $\mathrm{H}_{2}$ sensor based on vertically aligned edge-oriented $\mathrm{MoS}_{2}$ nanostructured thin film functionalized by Pd nanoparticles. Sens. Actuators B Chem. 2020, 325, 128800. [CrossRef]

53. Liang, J.; Li, W.; Liu, J.; Hu, M. Room temperature $\mathrm{CH}_{4}$ sensing properties of $\mathrm{Au}$ decorated $\mathrm{VO}_{2}$ nanosheets. Mat. Lett. 2016, 184, 92-95. [CrossRef]

54. Yuan, L.; $\mathrm{Hu}, \mathrm{M}$.; Wei, Y.; Ma, W. Enhanced $\mathrm{NO}_{2}$ sensing characteristics of $\mathrm{Au}$ modified porous silicon/thorn-sphere-like tungsten oxide composites. Appl. Surf. Sci. 2016, 389, 824-834. [CrossRef]

55. Li, W.; Xu, H.; Zhai, T.; Wang, J.; Cao, B. Enhanced triethylamine sensing properties by designing Au@SnO $2 / \mathrm{MoS}_{2}$ nanostructure directly on alumina tubes. Sens. Actuators B Chem. 2017, 253, 97-107. [CrossRef]

56. Hao, L.; Liu, Y.; Du, Y.; Xu, Z.; Zhu, J. Highly Enhanced $\mathrm{H}_{2}$ Sensing Performance of Few-Layer $\mathrm{MoS}_{2} / \mathrm{SiO}_{2} / \mathrm{Si}$ Heterojunctions by Surface Decoration of Pd Nanoparticles. Nanoscale Res. Lett. 2017, 12, 567. [CrossRef]

57. Vernieres, J.; Steinhauer, S.; Zhao, J.; Grammatikopoulos, P.; Sowwan, M. Gas Phase Synthesis of Multifunctional Fe-Based Nanocubes. Adv. Funct. Mater. 2017, 27, 1605328. [CrossRef]

58. Dhall, S.; Sood, K.; Nathawat, R. Room temperature hydrogen gas sensors of functionalized carbon nanotubes based hybrid nanostructure: Role of Pt sputtered nanoparticles. Int. J. Hydrogen Energy 2017, 42, 8392-8398. [CrossRef]

59. Song, X.; Xu, Q.; Xu, H.; Cao, B. Highly sensitive gold-decorated zinc oxide nanorods sensor for triethylamine working at near room temperature. J. Colloid Interf. Sci. 2017, 499, 67-75. [CrossRef] [PubMed] 
60. Munasinghe Arachchige, H.M.M.; Zappa, D.; Poli, N.; Gunawardhana, N.; Comini, E. Gold functionalized MoO3 nano flakes for gas sensing applications. Sens. Actuators B Chem. 2018, 269, 331-339. [CrossRef]

61. Xie, B.; Mao, P.; Chen, M.; Liu, J.M.; Wang, G. Pd Nanoparticle Film on a Polymer Substrate for Transparent and Flexible Hydrogen Sensors. ACS Appl. Mater. Interfaces 2018, 10, 44603-44613. [CrossRef]

62. Koo, A.; Yoo, R.; Woo, S.P.; Lee, H.S.; Lee, W. Enhanced acetone-sensing properties of pt-decorated al-doped ZnO nanoparticles. Sens. Actuators B Chem. 2019, 280, 109-119. [CrossRef]

63. Chen, Z.; Xu, H.; Liu, C.; Wang, J.; Cao, B. Good triethylamine sensing properties of Au MoS 2 nanostructures directly grown on ceramic tubes. Mater. Chem. Phys. 2020, 245, 122683. [CrossRef]

64. Chen, M.; Mao, P.; Qin, Y.; Liu, J.M.; Wang, G. Response Characteristics of Hydrogen Sensors Based on PMMA-Membrane-Coated Palladium Nanoparticle Films. ACS Appl. Mater. Interfaces 2017, 9, 27193-27201. [CrossRef]

65. Sysoev, V.V.; Schneider, T.; Goschnick, J.; Strelcov, E.; Kolmakov, A. Percolating $\mathrm{SnO}_{2}$ nanowire network as a stable gas sensor: Direct comparison of long-term performance versus $\mathrm{SnO}_{2}$ nanoparticle films. Sens. Actuators B Chem. 2009, 139, 699-703. [CrossRef]

66. Shaalan, N.M.; Yamazaki, T.; Kikuta, T. Influence of morphology and structure geometry on $\mathrm{NO}_{2}$ gas-sensing characteristics of $\mathrm{SnO}_{2}$ nanostructures synthesized via a thermal evaporation method. Sens. Actuators B Chem. 2011, 153, 11-16. [CrossRef]

67. Bhatnagar, M.; Dhall, S.; Kaushik, V.; Kaushal, A.; Mehta, B.R. Improved selectivity of SnO ${ }_{2}: \mathrm{C}_{\text {alloy }}$ nanoparticles towards $\mathrm{H}_{2}$ and ethanol reducing gases; role of $\mathrm{SnO}_{2}: \mathrm{C}$ electronic interaction. Sens. Actuators B Chem. 2017, 246, 336-343. [CrossRef]

68. Vasiliev, A.A.; Varfolomeev, A.E.; Volkov, I.A.; Jahatspanian, I.E.; Maeder, T. Reducing humidity response of gas sensors for medical applications: Use of spark discharge synthesis of metal oxide nanoparticles. Sensors 2018, 18, 2600. [CrossRef]

69. Skotadis, E.; Tang, J.; Tsouti, V.; Tsoukalas, D. Chemiresistive sensor fabricated by the sequential ink-jet printing deposition of a gold nanoparticle and polymer layer. Microelectron. Eng. 2010, 87, 2258-2263. [CrossRef]

70. Tang, J.; Skotadis, E.; Stathopoulos, S.; Roussi, V.; Tsouti, V.; Tsoukalas, D. PHEMA functionalization of gold nanoparticles for vapor sensing: Chemi-resistance, chemi-capacitance and chemi-impedance. Sens. Actuators B Chem. 2012, 2170, 129-136. [CrossRef]

71. Skotadis, E.; Mousadakos, D.; Katsabrokou, K.; Stathopoulos, S.; Tsoukalas, D. Flexible polyimide chemical sensors using platinum nanoparticles. Sens. Actuators B Chem. 2013, 189, 106-112. [CrossRef]

72. Madianos, L.; Skotadis, E.; Patsiouras, L.; Filippidou, M.K.; Chatzandroulis, S.; Tsoukalas, D. Nanoparticle based gas-sensing array for pesticide detection. J. Environ. Chem. Eng. 2018, 6, 6641-6646. [CrossRef]

73. Skotadis, E.; Kanaris, A.; Aslanidis, E.; Michalis, P.; Kalatzis, N.; Chatzipapadopoulos, F.; Marianos, N.; Tsoukalas, D. A sensing approach for automated and real-time pesticide detection in the scope of smart-farming. Comput. Electron. Agric. 2020, 78, 105759. [CrossRef]

74. Afify, A.S.; Hassan, M.; Piumetti, M.; Peter, I.; Bonelli, B.; Tulliani, J.M. Elaboration and characterization of modified sepiolites and their humidity sensing features for environmental monitoring. Appl. Clay Sci. 2015, 115, 165-173. [CrossRef]

75. Hassan, M.; Afify, A.S.; Tulliani, J.M. Synthesis of ZnO Nanoparticles onto Sepiolite Needles and Determination of Their Sensitivity toward Humidity. $\mathrm{NO}_{2}$ and $\mathrm{H}_{2}$. J. Mater. Sci. Technol. 2016, 32, 573-582. [CrossRef]

76. Hou, C.; Liu, H.; Zhang, D.; Yang, C.; Zhang, M. Synthesis of ZnO nanorods-Au nanoparticles hybrids via in-situ plasma sputtering-assisted method for simultaneous electrochemical sensing of ascorbic acid and uric acid. J. Alloy. Compd. 2016, 666, 178-184. [CrossRef]

77. Li, H.; Wang, W.; Lv, Q.; Bai, H.; Zhang, Q. Disposable paper-based electrochemical sensor based on stacked gold nanoparticles supported carbon nanotubes for the determination of bisphenol. Electrochem. Commun. 2016, 68, 104-107. [CrossRef]

78. Skotadis, E.; Voutyras, K.; Chatzipetrou, M.; Tsekenis, G.; Patsiouras, L.; Madianos, L.; Chatzandroulis, S.; Zergioti, I.; Tsoukalas, D. Label-free DNA biosensor based on resistance change of platinum nanoparticles assemblies. Biosens. Bioelectron. 2016, 81, 388-394. [CrossRef]

79. Yuan, Y.; Zhang, F.; Wang, H.; Zheng, Y.; Hou, S. Chemical vapor deposition graphene combined with Pt nanoparticles applied in non-enzymatic sensing of ultralow concentrations of hydrogen peroxide. RSC Adv. 2017, 7, 30542-30547. [CrossRef] 
80. Galdino, N.M.; Brehm, G.S.; Bussamara, R.; Abarca, G.; Scholten, J.D. Sputtering deposition of gold nanoparticles onto graphene oxide functionalized with ionic liquids: Biosensor materials for cholesterol detection. J. Mater. Chem. B 2017, 5, 9482-9486. [CrossRef]

81. Gasparotto, G.; Costa, J.P.C.; Costa, P.I.; Zaghete, M.A.; Mazon, T. Electrochemical immunosensor based on $\mathrm{ZnO}$ nanorods-Au nanoparticles nanohybrids for ovarian cancer antigen CA-125 detection. Mater. Sci. Eng. C 2017, 76, 1240-1247. [CrossRef] [PubMed]

82. Yuan, Y.; Zheng, Y.; Liu, J.; Wang, H.; Hou, S. Non-enzymatic amperometric hydrogen peroxide sensor using a glassy carbon electrode modified with gold nanoparticles deposited on CVD-grown graphene. Microchim. Acta 2017, 184, 4723-4729. [CrossRef]

83. Skotadis, E.; Tsekenis, G.; Chatzipetrou, M.; Patsiouras, L.; Madianos, L.; Bousoulas, P.; Zergioti, I.; Tsoukalas, D. Heavy metal ion detection using DNAzyme-modified platinum nanoparticle networks. Sens. Actuators B Chem. 2017, 239, 962-969. [CrossRef]

84. Madianos, L.; Tsekenis, G.; Skotadis, E.; Patsiouras, L.; Tsoukalas, D. A highly sensitive impedimetric aptasensor for the selective detection of acetamiprid and atrazine based on microwires formed by platinum nanoparticles. Biosens. Bioelectron. 2018, 101, 268-274. [CrossRef]

85. Madianos, L.; Skotadis, E.; Tsekenis, G.; Patsiouras, L.; Tsigkourakos, M.; Tsoukalas, D. Impedimetric nanoparticle aptasensor for selective and label free pesticide detection. Microelectron. Eng. 2018, 189, 39-45. [CrossRef]

86. Biasotto, G.; Costa, J.P.C.; Costa, P.I.; Zaghete, M.A. ZnO nanorods-gold nanoparticle-based biosensor for detecting hepatitis C. Appl. Phys. A 2019, 125, 821. [CrossRef]

87. Danielson, E.; Dhamodharan, V.; Porkovich, A.; Yokobayashi, Y.; Sowwan, M. Gas-Phase Synthesis for Label-Free Biosensors: Zinc-Oxide Nanowires Functionalized with Gold Nanoparticles. Sci. Rep. 2019, 9 , 17370. [CrossRef]

88. Danielson, E.; Sontakke, V.A.; Porkovich, A.J.; Yokobayashi, Y.; Sowwan, M. Graphene based field-effect transistor biosensors functionalized using gas-phase synthesized gold nanoparticles. Sens. Actuators B Chem. 2020, 320, 128432. [CrossRef]

89. Della Ventura, B.; Funari, R.; Anoop, K.K.; Amoruso, S.; Ausanio, G.; Gesuele, F.; Velotta, R.; Altucci, C. Nano-machining of biosensor electrodes through gold nanoparticles deposition produced by femtosecond laser ablation. Appl. Phys. B 2015, 119, 497-501. [CrossRef]

90. Said, K.; Ayesh, A.I.; Qamhieh, N.N.; Mahmoud, S.T.; Hisaindee, S. Fabrication and characterization of graphite oxide-nanoparticle composite based field effect transistors for non-enzymatic glucose sensor applications. J. Alloy. Compd. 2017, 694, 1061-1066. [CrossRef]

91. Jung, D.U.J.; Ahmad, R.; Hahn, Y.B. Nonenzymatic flexible field-effect transistor based glucose sensor fabricated using $\mathrm{NiO}$ quantum dots modified $\mathrm{ZnO}$ nanorods. J. Colloid. Interf. Sci. 2018, 512, 21-28. [CrossRef]

92. Soganci, T.; Ayranci, R.; Harputlu, E.; Unlu, C.G.; Ak, M. An effective non-enzymatic biosensor platform based on copper nanoparticles decorated by sputtering on CVD graphene. Sens. Actuators B Chem. 2018, 273, 1501-1507. [CrossRef]

93. Olejnik, A.; Siuzdak, K.; Karczewski, J.; Grochowska, K. A Flexible Nafion Coated Enzyme-free Glucose Sensor Based on Au-dimpled Ti Structures. Electroanalysis 2020, 32, 323-332. [CrossRef]

94. Zhang, T.; Ran, J.; Ma, C.; Yang, B. A Universal Approach to Enhance Glucose Biosensor Performance by Building Blocks of Au Nanoparticles. Adv. Mater. Interfaces 2020, 7, 2000227. [CrossRef]

95. Soganci, T.; Ayranci, R.; Unlu, G.; Acet, M.; Ak, M. Designing sandwich-type single-layer graphene decorated by copper nanoparticles for enhanced sensing properties. J. Phys. D Appl. Phys 2020, 53, 255105. [CrossRef]

Publisher's Note: MDPI stays neutral with regard to jurisdictional claims in published maps and institutional affiliations.

(C) 2020 by the authors. Licensee MDPI, Basel, Switzerland. This article is an open access article distributed under the terms and conditions of the Creative Commons Attribution (CC BY) license (http://creativecommons.org/licenses/by/4.0/). 